\title{
THE USE OF THE PARETO-LORENZ DIAGRAM FOR QUALITATIVE ANALYSIS OF STEEL RIMS
}

\author{
${ }^{1}$ Renata CABAN \\ ${ }^{1}$ Czestochowa University of Technology, Faculty of Production Engineering and Materials Technology, \\ Department of Materials Engineering, Czestochowa, Poland, EU, caban.renata@wip.pcz.pl
}

https://doi.org/10.37904/metal.2020.3660

\begin{abstract}
One of the most commonly used methods of quality management in manufacturing and industrial enterprises is the Pareto-Lorenz analysis. This method is currently one of the most frequently used conventional tools for the improvement the product quality and processes. It is a very useful tool used in the analysis of a production or service processes that generate variables that can be categorized. The Pareto-Lorenz chart is a graphical representation of the frequency of the causes of the problem (graph in the form of a bar graph) and their cumulative values (Lorenz curve). The impact of Pareto analysis on product quality occurs mainly through the analysis of the frequency and significance of non-compliance, elimination of quality problems occurring in the enterprise most often and elimination of quality problems generating the highest costs. The purpose of the work was to analyse the quality of steel wheels manufactured by one of the companies in Poland. Steel wheels are standard equipment on cars. Their biggest advantage is durability, both mechanical and chemical. As a result of the analysis, three main causes of steel rims complaints were identified. These are edge bumps, damaged coating (splinters) and material defects. The identified causes represent a good starting point for works aimed to propose concrete preventive actions which, if implemented, should reduce the number of occurrences of certain types of defects without the need for expensive large-scale actions.
\end{abstract}

Keywords: Quality management methods, car parts production, Pareto-Lorenz diagram

\section{INTRODUCTION}

The problems of the quality of manufactured products are currently one of the most important issues addressed in the field of enterprises management. All quality management tools are instruments which allow for very effective monitoring of all processes, activities, and individual operations throughout the entire product life cycle [1]. In the production of car parts, the level of quality is particularly important because it has also an effect on human safety and life $[2,3]$. The quality of the finished products, that is vehicles, largely depends on the quality of its components, that is car parts manufactured by various companies. Therefore, the quality of individual components is extremely important since they form a finished product, that is a product that reaches the customer. If the product has defects, it does not meet customer expectations. In such cases, the most important thing is to determine the causes of the defects. The Pareto analysis is very often used to determine the causes and effects of defects in a product or manufacturing process in the automotive industry [4]. This method allows for the analysis of the structure of the manufacturing process. It helps identify the stage of the process at which defects occur. After analysis using the Pareto method, the company can take corrective and preventive measures to avoid similar product defects or manufacturing process errors in the future. The purpose of the work was to analyse the quality of steel wheels manufactured by one of the companies in Poland. The identified causes represent a good starting point for works aimed to propose concrete preventive actions which, if implemented, should reduce the number of occurrences of certain types of defects without the need for expensive large-scale actions. 


\section{METHODOLOGY OF RESEARCH}

The Pareto analysis is based on the empirically established pattern that $20 \%$ of causes determine $80 \%$ of effects. This regularity was first discovered and described by the Italian economist and sociologist Vilfredo Federico Damaso Pareto. Using statistical data, he analysed the distribution of incomes of the population in designated ranges. Pareto observed that $80 \%$ of Italian resources were held by $20 \%$ of families. He found the occurrence of such an uneven distribution also in other situations and formulated a principle known today as the $80 / 20$ rule. This principle states that roughly $20 \%$ of the elements represent about $80 \%$ of the cumulative value. The $80 / 20$ rule offers the opportunity for definition of the main directions of activities focusing on the most important problems, within which the measures taken allow for the achievement of the maximum effects [5]. The main areas of application of the Pareto analysis are illustrated in Figure 1.

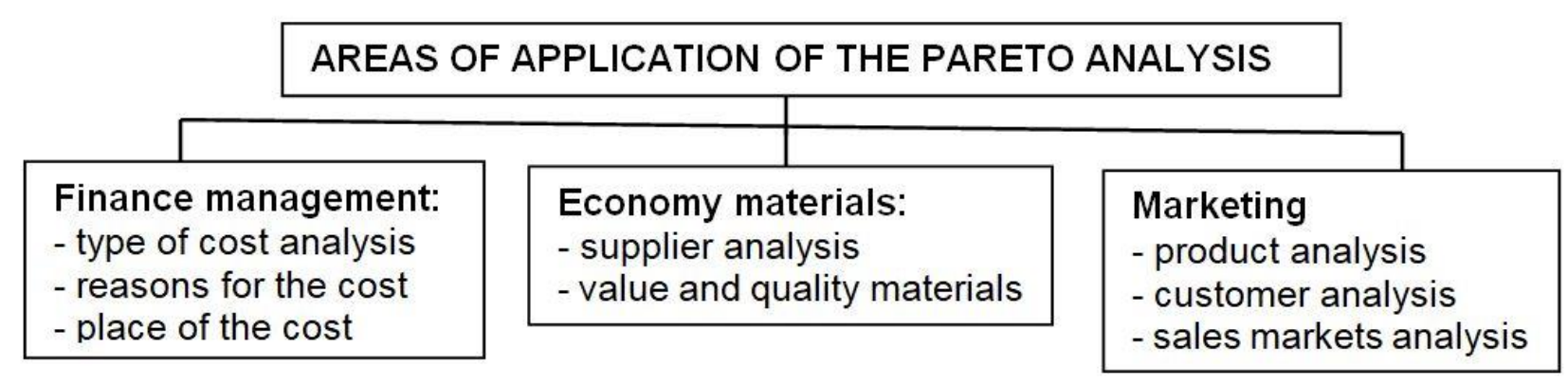

Figure 1 Areas of application of the Pareto analysis

The Pareto analysis is also used in quality management. The Pareto chart is currently one of the most frequently used conventional tools for the improvement of product quality and processes. It is a very useful tool employed in the analysis of a production or service processes that generates variables that can be categorized [6]. The Pareto-Lorenz diagram is a graphical representation of the frequency of occurrence of the causes of a problem (chart in the form of a bar chart) and their cumulative values (Lorenz curve). The stages of creating the Pareto chart are shown in Figure 2.

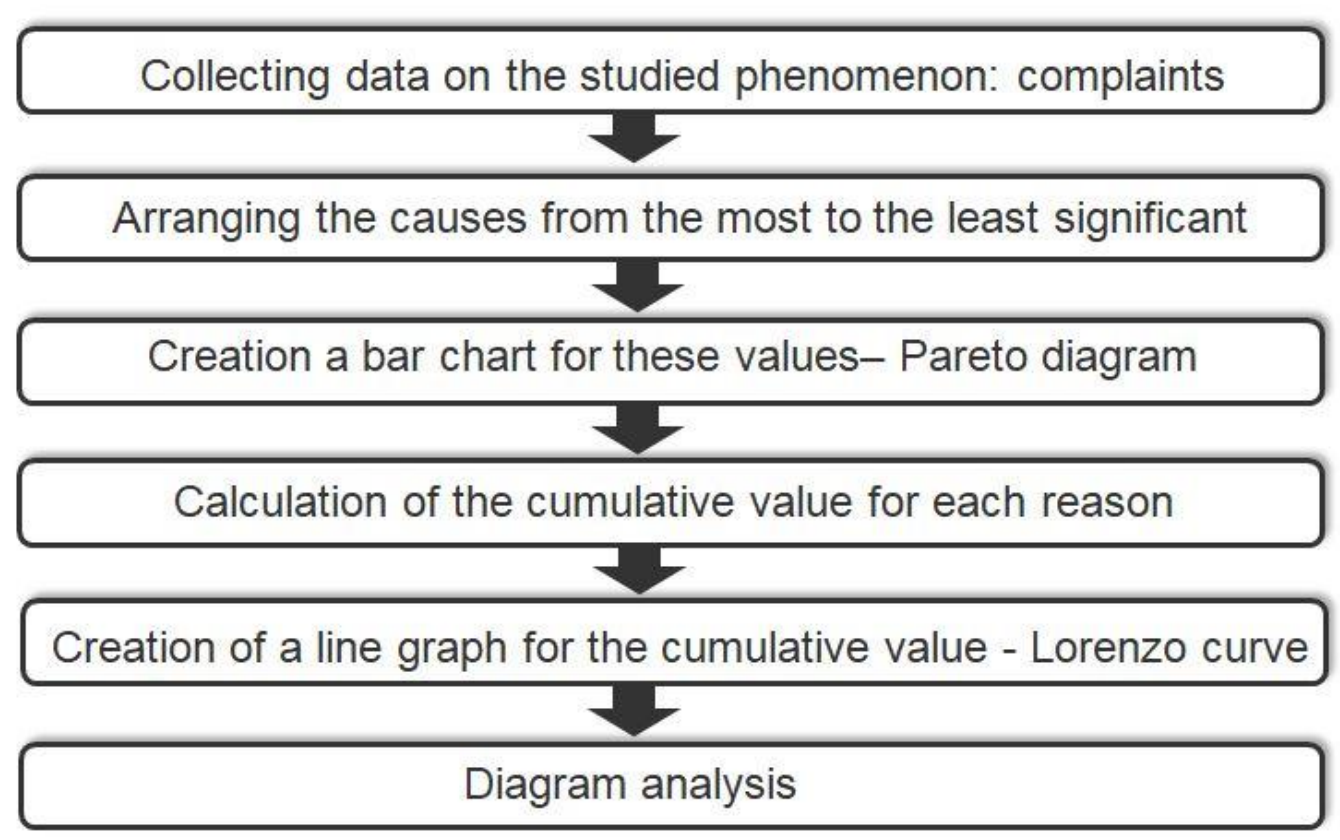

Figure 2 Algorithm of the Pareto analysis procedure 


\section{RESULTS}

The data presented in the paper come from a company producing steel car wheel rims. Steel rims usually represent standard equipment in passenger cars. They are much cheaper compared to aluminium wheel rims. The biggest advantage of steel products, including steel rims, is their mechanical strength and chemical resistance [7]. Furthermore, compared to aluminium rims, they are much easier to clean. Steel wheel rims are manufactured using highly advanced technologies. Typically, manufacturing of steel wheel rims is divided into four stages:

- manufacturing of a wheel disc,

- manufacturing of a rim,

- assembly,

- varnishing.

Initial fixing holes and the central hole are made in each steel rim. The correct performance of the above steps determines the quality of the final product. An analysis of the number of complaints filed by customers within one quarter of a year was made in the company. One of the quality management tools, that is Pareto chart was used for this purpose [8]. Based on all reported product inconsistencies with the specifications, a list of causes of defects that are reported by customers was prepared. The list of all identified causes of complaints and the number of their occurrences are shown in Table 1.

Table 1 The list of all identified causes of complaints and the number of their occurrences

\begin{tabular}{|c|c|c|}
\hline No. & Type of a complaints & 26 \\
\hline 1. & Material defects & 2 \\
\hline 2. & Geometrical dimensions outside specification & 1 \\
\hline 3. & Dynamic dimensions outside specification & 45 \\
\hline 4. & Damage to the coating - splinters & 4 \\
\hline 5. & Corrosion & 14 \\
\hline 6. & Unpainted area & 11 \\
\hline 7. & Spacing, position of fixing holes & 70 \\
\hline 8. & Mechanical damage of edge & 2 \\
\hline 9. & Incompatible label & 9 \\
\hline 10. & Mistaked parts in box & 3 \\
\hline 11. & Damage to the packaging & 1 \\
\hline 12. & Balancing error & 1 \\
\hline 13. & Cracks & \\
\hline
\end{tabular}

The data were further arranged in a descending order with regard to the number of complaints. Next, their percentages and a cumulative value were calculated. The results of the Pareto analysis are presented in Table 2.

Table 2 The list of all identified causes of complaints and the number of their occurrences

\begin{tabular}{|c|c|c|c|c|}
\hline No. & Type of a complaints & Frequency & $\begin{array}{c}\text { Percentage } \\
(\%)\end{array}$ & $\begin{array}{c}\text { Cumulative value } \\
(\%)\end{array}$ \\
\hline 8. & Mechanical damage of edge & 70 & 37.04 & 37.0 \\
\hline 4. & Damage to the coating - splinters & 45 & 23.81 & 60.8 \\
\hline 1. & Material defects & 26 & 13.76 & 74.6 \\
\hline
\end{tabular}




\begin{tabular}{|c|c|c|c|c|}
\hline 6. & Unpainted area & 14 & 7.41 & 82.0 \\
\hline 7. & Spacing. position of fixing holes & 11 & 5.82 & 87.8 \\
\hline 10. & Mistaked parts in box & 9 & 4.76 & 92.6 \\
\hline 5. & Corrosion & 4 & 2.12 & 94.7 \\
\hline 11. & Damage to the packaging & 3 & 1.59 & 96.3 \\
\hline 2. & Geometrical dimensions outside & 2 & 1.06 & 97.4 \\
\hline 9. & specification & 2 & 1.06 & 98.4 \\
\hline 3. & Incompatible label & 1 & 0.52 & 98.9 \\
\hline 12. & Balancing error & 1 & 0.52 & 99.5 \\
\hline 13. & Cracks & 1 & 0.53 & 100.0 \\
\hline
\end{tabular}

The results contained in Table 2 were used to prepare a Pareto chart as shown in Figure 3.

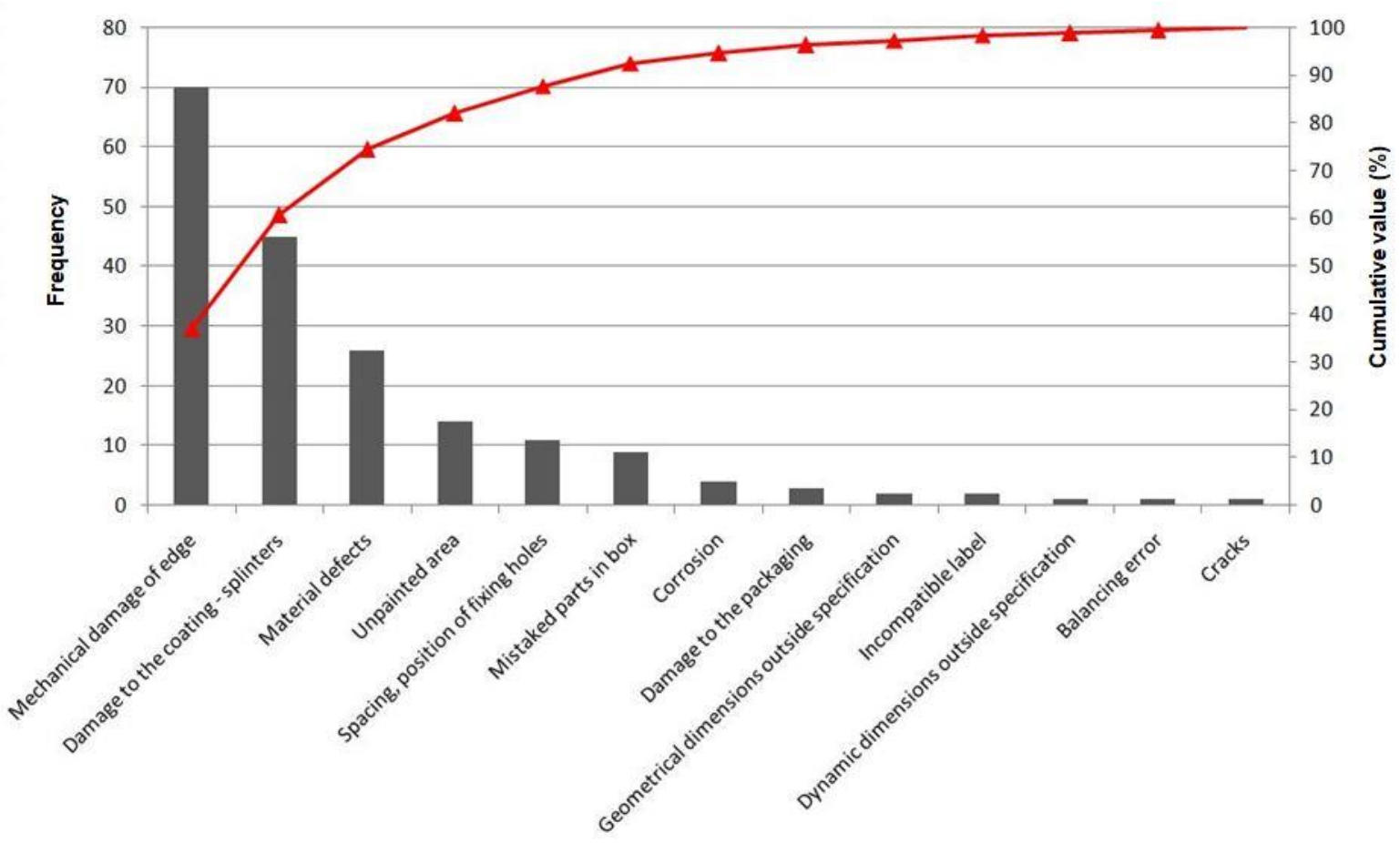

Figure 3 Pareto-Lorenz diagram

\section{DISCUSSION}

Figure 3 illustrates the results of the Pareto analysis. The axis of the abscissae represents the causes of complaints, whereas the axis of the ordinates contains the cumulative frequency of complaints. Both the graph (Figure 3) and Table 2 show that out of 13 types of causes of complaints, three have the dominant role in roughly $75 \%$ of the effects. These include: mechanical edge damage $(37.04 \%)$, damage to the chipping splinters $(23.81 \%)$ and material defects $(13.76 \%)$. The other causes for the complaints account for about 25 $\%$. The causes of the first 2 defects (with the highest frequency) may be the failure to observe the technological process by employees resulting from low skills, negligence and from the conditions of storage and transport of the products to the customer. It should be noted that the three rarest causes of complaints accounted for about $1.6 \%$ of all quality problems, and these were: dynamic dimensions not meeting the specifications, steel rims which could not be balanced and cracks. 


\section{CONCLUSION}

An analysis of the number of complaints filed by customers within one quarter of a year was made in the company. As a result of the analysis, three main causes of steel rims complaints were identified. These are edge bumps, damaged coating (splinters) and material defects. The identified causes represent a good starting point for works aimed to propose concrete preventive actions which, if implemented, should reduce the number of occurrences of certain types of defects without the need for expensive large-scale actions. Analysis and improvement of product quality are very important, especially in the automotive sector. These actions allow for maintaining appropriate quality parameters of the product, which is also important from the standpoint of safety of its use. The results of this study should be further analysed using other quality management methods, which will undoubtedly lead to the improvement in the quality of the product.

\section{REFERENCES}

[1] CHĄDZYŃSKA, M., KLIMECKA - TATAR, D. Identyfikacja występujących przyczyn niezgodności za pomocą diagramu Pareto - Lorenza - produkcja wyrobów kaletniczych. Archiwum Wiedzy Inżynierskiej. 2017, vol. 2, no. 1, pp. 32-34.

[2] WĄSOWICZ, A., BOROWIAK, J. Badania procesów logistycznych w motoryzacji. Logistyka. Autobusy. 2019, vol. 3, pp. 66-70.

[3] SOŃTA, G., DUDEK, A., SALEJDAK, J., ULEWICZ, R. Analysis of structure of elements for Automotive Industry. Applied Mechanics and materials. 2015, vol. 712, pp. 81-86.

[4] KIPIGROCH, M., PÓŁROLNIK, A., KARDAS, E. Analiza i doskonalenie jakości w wybranym przedsiębiorstwie produkcyjnym. Systemy wspomagania w inżynierii produkcji. 2017, vol. 6, no. 9, 9-23.

[5] SZCZEŚSNIAK, B., ZASADZIEŃ, M., WAPIENIK, Ł. Zastosowanie analizy Pareto oraz diagramu Ishikawy do analizy przyczyn odrzutów w procesie produkcji silników elektrycznych. Zeszyty Naukowe Politechniki Śląskiej. Seria: Organizacja i zarządzanie. 2012, z.63a, pp. 125 - 147.

[6] KOWALIK, K. Diagram Pareto - Lorenza w teorii i praktyce zarządzania jakością. Archiwum Wiedzy Inżynierskiej. 2018, vol. 3, no. 1, pp. 22-24.

[7] GWOŹDZIK, M., KULESZA, S., BRAMOWICZ, M., BAŁAGA, Z. Surface Morphology Analysis of Martensitic Stainless Steel after Different Treatments. Acta Physica Polonica A. 2019, vol. 135, no. 2, pp. 157-161.

[8] BORKOWSKI, S. Mierzenie poziomu jakości. Wydawnictwo Wyższej Szkoły Zarządzania i Marketingu. Sosnowiec, 2004. 